RAJMUND MANN

KAMIL CZERWIŃSKI

KAMIL MATUSIK

\title{
Analysis of cutting picks trajectory and cutterhead vibrations of roadheader with use of high-speed cameras
}

\begin{abstract}
In order to identify the behavior of cutting picks during the process of mining with the use of a roadheader's cutterhead, an optic system has been employed. The main elements of the system were high-speed cameras. In conjunction with TEMA Motion 3D software (which is designed to analyze movement based on images registered in videos), this allowed for a detailed analysis of the trajectories of the boom, cutterheads, and cutting picks during the process of cutting. This article presents the process of conducting measurements as well as the results of a comparative analysis of the boom vibrations and movement trajectories of cutting picks on the cutterhead for selected cut types: progressive and degressive.
\end{abstract}

Key words: high-speed camera, roadheader, transverse cutterheads, progressive cut, degressive cut, vibrations

\section{INTRODUCTION}

From the point of view of a multi-pick cutterhead, defining the instantaneous position of cutting picks is essential for linking them with the forces generated during mining. Depending on the rotational speed of the cutterheads and boom extension speed, consecutive picks entering the cutting zone can make new cuts or fall into grooves made by previous picks [1]. Additionally, the modification of these parameters impacts the shape of the cross-section area of the cut [2-6]. An analysis of the load characteristics of picks (which is necessary for verifying the numerical model of a roadheader [7-10] and automatically control the parameters of the machine during mining [11]) requires the identification of the actual movement trajectories of the picks (where cutting, compression, and lateral forces are measured) and the roadheader vibrations (especially of its excavating system components). Using an external optical system of high-speed cameras (that are not a part of the machine) that is precise enough to define the position changes of the cutterheads and their picks is an alternative method to a direct measurement [12]. Taking into account the complex movement trajectory of the transverse cutterhead (where the picks move in a spiral motion over the torus surface during the cutting process, which is impacted by overlapping vibrations of the boom and the whole machine), using an optical measurement system to identify displacements of selected points on the boom and the roadheader cutterhead have proven to be the right solution.

\section{TEST STATION}

The measurements were conducted at a test station [13] at the Department of Mining Mechanization and Robotization of the Faculty of Mining and Geology 
at the Silesian University of Technology; this station was built as a part of the "Controlling the movement of roadheader cutterheads to decrease energy consumption and dynamic loads" research project co-financed by NCBiR (the National Center of Studies and Research).

In order to conduct optical measurements to define the movement of the cutterhead, the test station had to be additionally prepared (Fig. 1). One of the basic requirements for image analysis is the filming of fixed reference points used to positioncoordinate systems in space while moving with the object. The method used for measurement required that these reference points were situated on the same plane. Taking into account the conditions at the work station, the only solution to meet these requirements was to anchor a slab with quadrant markers to a concrete block. The slab was placed above the planned cuts.

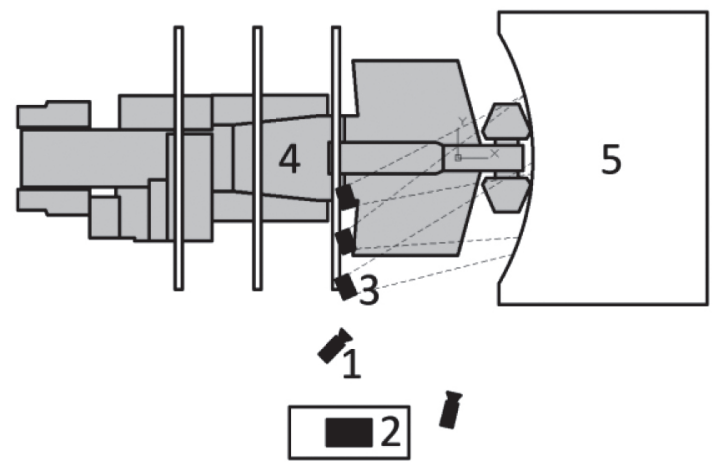

Fig. 1. Layout of components of optical measurement system at test station: 1 - cameras; 2 - camera operation station; 3 - lighting; 4 - roadheader; 5 - concrete block

Another condition required to conduct the analysis of the movement of objects in a 3D space is simultaneously filming them with two time-synchronized cameras placed in relation to the filmed objects in such a way that the angle between the optical axes is within the range defined for this measurement method. Therefore, the cameras were placed on tripods as widely apart as possible at the sides of the test station.

Just as important as the camera deployment around the test station is the appropriate lighting. Filming with the ultra-short registration times of each video frame requires a very bright and stable source of lighting (that does not pulse). For lighting the test station, special LED panels were used. They were placed on the arcs of mine roadway supports at the test station, and the light beams from each panel were directed in such a way as to concentrate the light at the place of measurement. The obtained light power enabled us to register the videos with a $1000 \mathrm{~Hz}$ frequency with the exposure time of a single video frame of $2 \times 10^{-5} \mathrm{~s}$. Such a short exposure time was required to avoid smudging (blurriness due to filmed-object movement) in the registered video.

The camera deployment around the test station and the use of proper lenses allowed us to frame the same area for both cameras, which included the end of the roadheader boom, the right cutterhead, the slab with markings, and the cutting area in the central part of the concrete block working face, approximately $1.5 \mathrm{~m}$ wide (Fig. 2).

a)

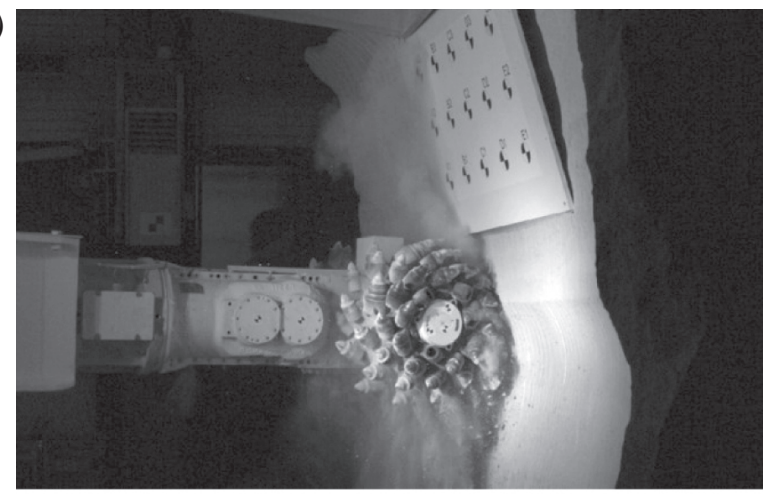

b)

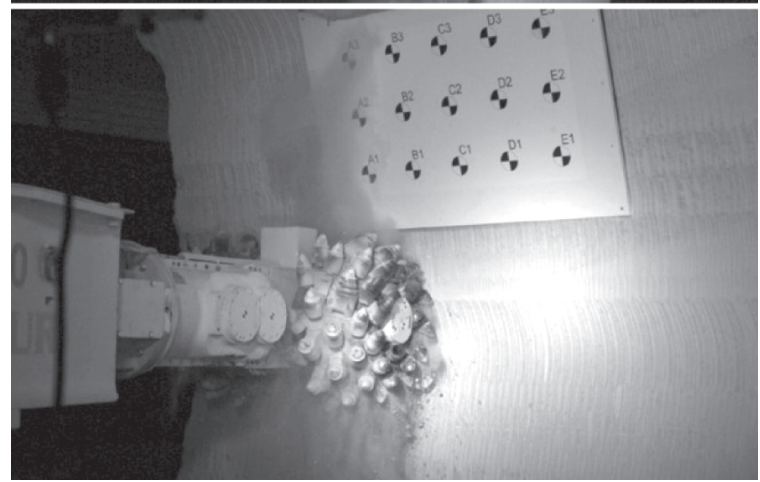

Fig. 2. View of area filmed by right (a) and left (b) cameras at test station during mining

In order to identify the movement of the cutterhead and boom, these objects also had to be equipped with markers so that the changes in their position could be clearly determined later during the analysis. In order to determine the changes of the boom position, two markers were attached to the reduction gear covers of the cutterhead drive. Whereas, in order to determine the movement trajectory of the cutterhead, three markers at its side cover were used due to the fact that the cutterhead also performs a rotary movement. 
The mining process of the concrete block was filmed at the prepared test station in 5-second takes (this was the maximum time for the internal memory of the high-speed cameras). This length of time, depending on the rotational speed of the cutterheads, enabled us to register between three and five full revolutions of the cutterheads.

\section{PROCESSING OF MEASUREMENT DATA}

The movement analysis was conducted with the use of TEMA Motion 3D software. This included the determination of marker positions on the reference slab, boom, and cutterhead in the registered images as well as a determination of a spatial coordinate system common to both cameras, a determination of correction factors for lens distortion (in order to eliminate the curvature of images), and the tracking changes of the marker positions (Fig. 3) on consecutive frames of the registered videos.

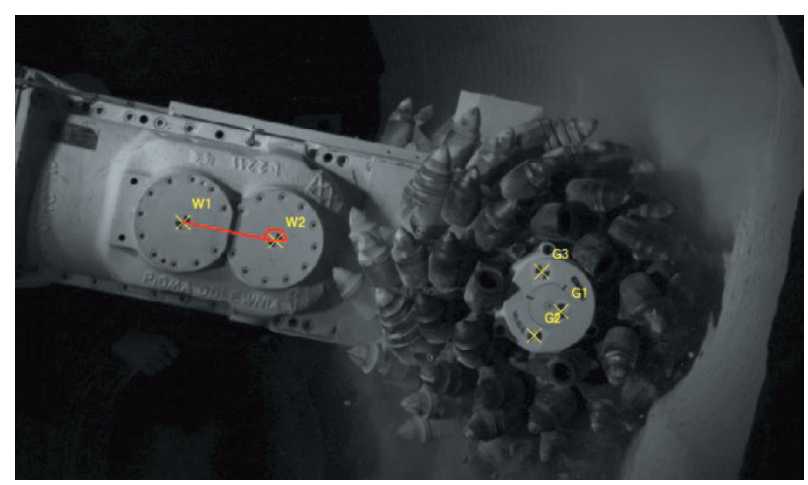

Fig. 3. Frame from software's interface to analyze TEMA Motion 3D image - virtual tracking points at boom and cutterhead

As a result of the conducted procedures, the $\mathrm{x}, \mathrm{y}$, and $\mathrm{z}$ coordinates of the markers on the reference slab and cutterhead (Fig. 4) as well as on the boom were obtained, reflecting their consecutive positions in their movement trajectory.

The coordinates of the points that determined the movement trajectory of the cutterhead set out in the TEMA Motion 3D software were exported. Later, they were matched with the coordinates of points that determined the cutting picks arrangement on the virtual model of the cutterhead obtained from a $3 \mathrm{D}$ scanner. The mutual correlation of the coordinate systems of the cutterhead model and cutterhead movement trajectory allowed us to determine the movement trajectory of the cutting picks on the cutterhead.

In the end, all movement trajectories were positioned on a Cartesian coordinate system related to the concrete block. The center of the system was located in the bottom right corner of the block. The " $y$ " axis was directed into the concrete block, while the " $x z$ " plane overlapped the plane of the concrete block's face (into which, the roadheader cutterheads were slumped), and the " $z$ " axis was directed vertically.

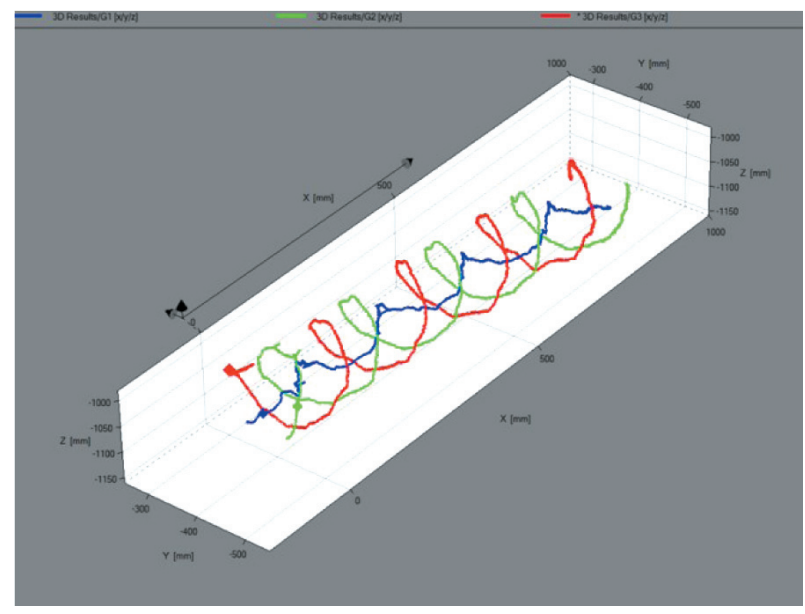

Fig. 4. Movement trajectories of cutterhead markers while performing one cut

Examples of the movement trajectories of the markers on the roadheader boom and the determined movement trajectories of the blades of three selected cutting picks are shown in Figure 5.

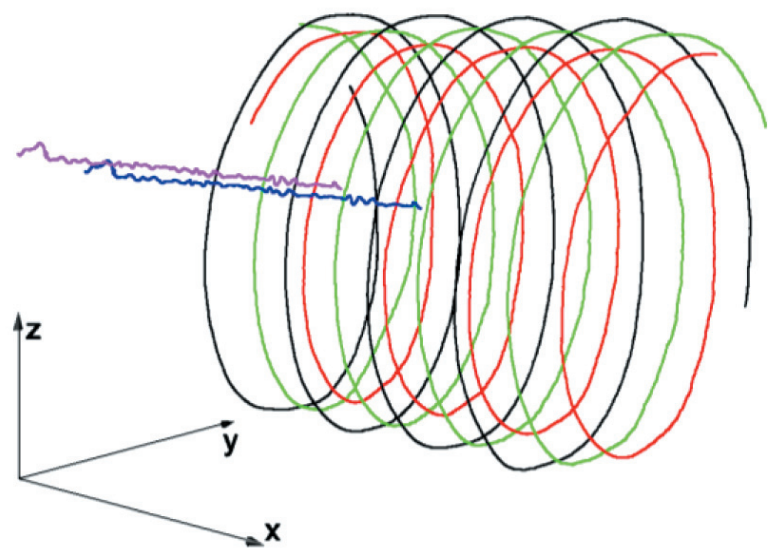

Fig. 5. Movement trajectories of markers on boom and three picks on cutterhead while performing one cut

During the analysis of the boom movement, the measurement error value was determined based on the time functions of the measured positions of the 
$\mathrm{W} 1$ and $\mathrm{W} 2$ points on the boom and the determined distance between them (Fig. 6).

$$
\begin{aligned}
& L_{w 1 w 2}=\sqrt{\left(\Delta x_{w}\right)^{2}+\left(\Delta y_{w}\right)^{2}+\left(\Delta z_{w}\right)^{2}} \\
& \Delta x_{w}=x_{w 2}-x_{w 1} \\
& \Delta y_{w}=y_{w 2}-y_{w 1} \\
& \Delta z_{w}=z_{w 2}-z_{w 1}
\end{aligned}
$$

where $x_{w 1, w 2}, y_{w 1, w 2}, z_{w 1, w 2}$ - the determined coordinates of points $\mathrm{W} 1$ and $\mathrm{W} 2$

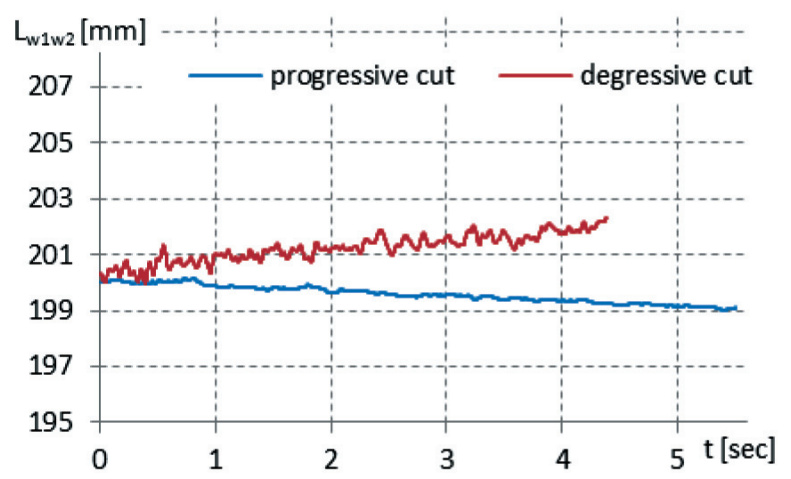

Fig. 6. Determining value of measurement error based on $W 1$ and $W 2$ point distance

The distance between the markers on the boom is $200 \mathrm{~mm}$. The distance, which measured during the movement of the boom with the use of the optical camera system, changed by $2 \mathrm{~mm}$, which translates to a measurement error of $1 \%$. The errors were mainly caused by dust, the vibrations transmitted to the structure of the building in which the measurement was conducted, and by errors during the determination of lens-distortion correction. Due to the fact that the spatial position of the cutterhead was determined analytically based on the position of the W1 and W2 points, the results of the analysis presented in this article are affected by a similar error.

\section{CUTTING PICKS MOVEMENT TRAJECTORIES AND BOOM VIBRATIONS}

This article presents the selected results of the roadheader's boom vibration analysis and movement trajectories of the cutting picks on the cutterhead during progressive and degressive cutting with a cutterhead rotational speed of $44.8 \mathrm{rpm}$.

Progressive cuts are cuts where the cutting depth gradually increases - usually starting from a value of zero. In the case of a roadheader equipped with transverse cutterheads, these are usually created while mining the working face with the horizontal movements of the boom when the rock is excavated below the previously existing breach (Fig. 7). Due to the position of these cuts in relation to the previous cut, they are also called lower cuts.

On the other hand, degressive cuts are cuts where the pick starts cutting with a certain initial depth that is the maximum depth of a cut in most cases; then, the depth of the cut gradually decreases (Fig. 7). These cuts are created by raising the cutterheads and mining the layer of rock above the existing breach; hence, another name for these cuts is "upper cuts."

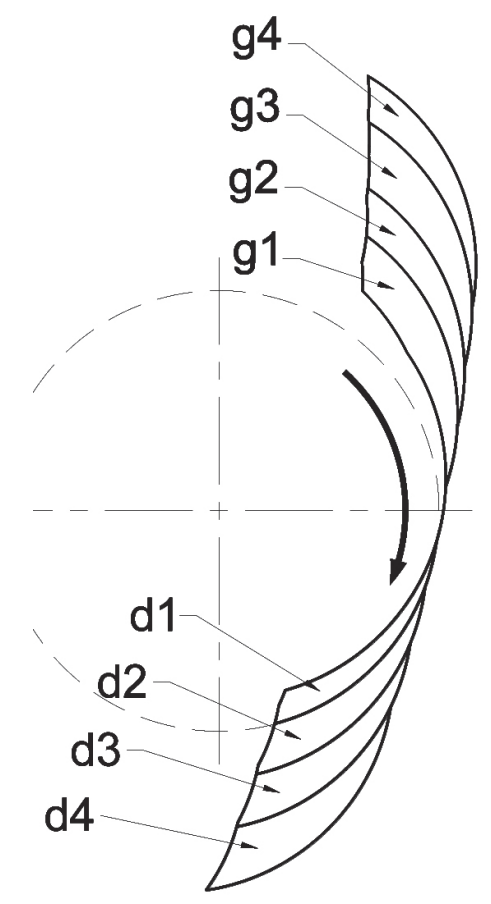

Fig. 7. Consecutive cuts performed by transverse cutterheads of the roadheader: $d$-lower (progressive),

$$
g \text { - upper (degressive) }
$$

While extending the boom in the plane parallel to the thill, the picks on the transverse cutterhead theoretically move in a spiral motion over the surface of toruses. However, due to the vibrations of the boom caused by the mining process, these trajectories are distorted; this in turn results in differences between the theoretical and actual shapes of the cuts [14]. Figure 8 shows the determined actual movement trajectories of three picks in the coordinate system related to the cutterhead where the " $x$ " axis matches the theoretical cutterhead rotation axis. The black dashed lines in the figure form circles that are the projection of the theoretical movement trajectories 
of the selected picks. For the presented pick-movement trajectories, deviations toward the " $y$ "” axis are significantly smaller than toward the " $z$ "” axis.

$$
\begin{aligned}
& z_{i}^{\prime}=z_{i}-z_{g t} \\
& y_{i}^{\prime}=y_{i} \cdot \cos \alpha_{H r}+x_{i} \cdot \sin \alpha_{H r}-y_{g t}
\end{aligned}
$$

where:

$$
\begin{aligned}
x_{i}, y_{i}, z_{i}- & \text { designated coordinates of the tips of the } \\
& \text { conical tools in the accepted main coor- } \\
& \text { dinate system, } \\
y_{g t}, z_{g t}- & \text { theoretical coordinates of the position } \\
& \text { of the cutterhead resulting from the set } \\
& \text { parameters and boom movement, } \\
\alpha_{H r}- & \text { real boom extension angle in the plane } \\
& \text { parallel to the thill. }
\end{aligned}
$$

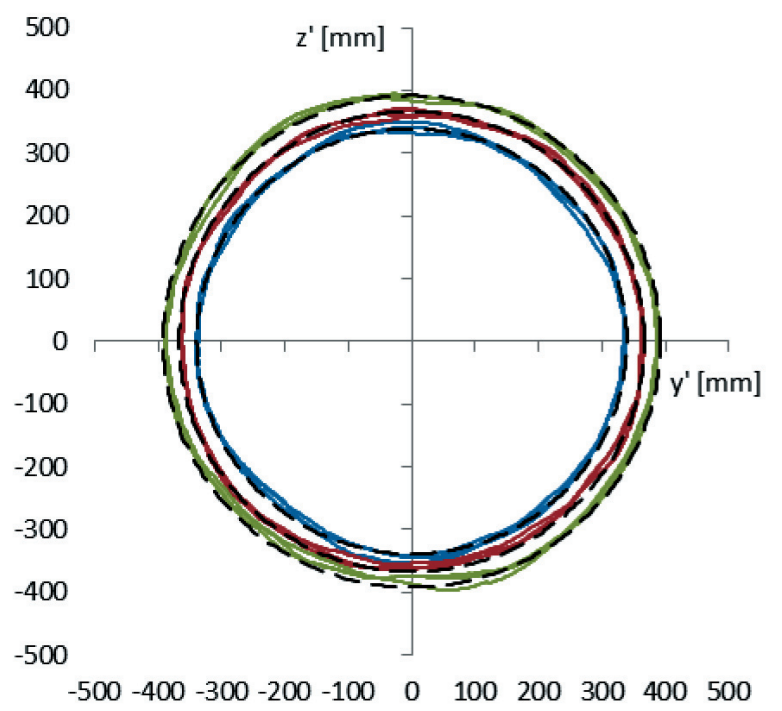

Fig. 8. Deviations of actual movement trajectories of cutting picks from theoretical trajectories caused

by vibrations of cutterhead, presented in plane perpendicular to cutterhead rotation axis

Determination of the vibrations of the boom and its cutterhead based on the movement trajectories of the picks is difficult due to their rotation movement in relation to the cutterhead rotation axis. This is why the vibration analysis of the cutterhead was conducted based on the reference points positioned on the body of the boom.

The resultant position of the cutterhead in relation to its theoretical position in affected by the vibrations of the whole machine body and of the boom in relation to the body (instantaneous changes of the boom extension angle in planes that are perpendicular and parallel to the thill). The area of the video frames allowed us to determine the torsional vibrations of the boom and the resultant cutterhead vibrations during the mining process.

The progressive cut presented in this article was performed with a theoretically determined boom extension angle in the plane perpendicular to the thill of $\alpha_{V}=-12.78^{\circ}$ and the degressive cut with an angle of $\alpha_{V}=-2.08^{\circ}$. In order to directly compare the intensity of the boom vibrations, these values were treated as a reference point equal to $0^{\circ}$ (Fig. 9).

$$
\Delta \alpha_{V}=\alpha_{V r}-\alpha_{V t}
$$

where:

$$
\begin{aligned}
\alpha_{V r}- & \text { real boom extension angle in the plane } \\
& \text { perpendicular to the thill, } \\
\alpha_{V t}- & \text { theoretical (given) boom extension angle } \\
& \text { in the plane perpendicular to the thill. }
\end{aligned}
$$

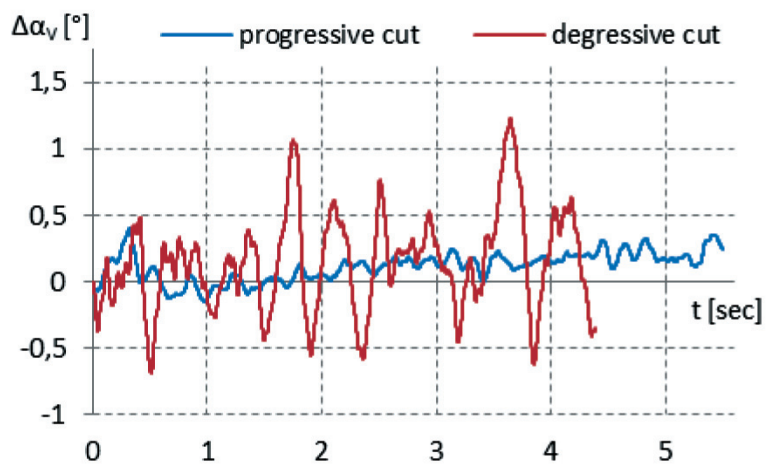

Fig. 9. Course of changes of boom extension angle in plane perpendicular to thill in relation to theoretical position

As seen from the presented characteristics, the amplitude of the angular displacements of the boom in the plane perpendicular to the thill while performing the degressive cut was even 3.5 times higher than with the progressive cut. In the case of the degressive cut, it reached up to $1.7^{\circ}$, while for the progressive cut - up to $0.5^{\circ}$. The displacements of the boom by the $\alpha_{V}$ angle caused by vibrations significantly affected the actual position of the cutterhead. Changing angle $\alpha_{V}$ by $1^{\circ}$ in the case of the analyzed roadheader type causes a displacement of the cutter head in the plane perpendicular to the thill by $54 \mathrm{~mm}$.

When mining horizontal layers, the extension angle of the boom in the plane perpendicular to thill $\alpha_{V}$ remains theoretically unchanged; however, the extension angle of the boom in the plane parallel to thill $\alpha_{H}$ changes, which is the result of the movement of the roadheader's turntable. In the presented examples, 
the boom was extended in the plane parallel to the thill with an average angular speed of $\omega_{H}=0.06 \mathrm{rad} / \mathrm{sec}$ for the degressive cut and $\omega_{H}=0.04 \mathrm{rad} / \mathrm{sec}$ for the progressive cut (Fig. 10).

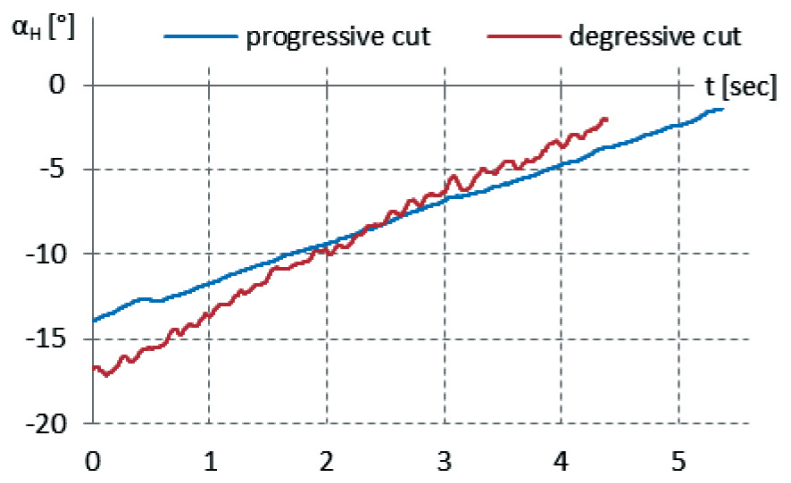

Fig. 10. Course of changes of boom extension angle in plane parallel to thill

In order to analyze the changes (vibrations) of extension angle $\alpha_{H}$, the theoretical instantaneous values of this angle due to turntable movement were treated as reference points and were assigned a value of $0^{\circ}$ (Fig. 11).

$$
\Delta \alpha_{H}=\alpha_{H r}-\alpha_{H t}
$$

where:

$$
\begin{aligned}
\alpha_{H r}- & \text { real boom extension angle in plane parallel } \\
& \text { to thill, } \\
\alpha_{H t}- & \text { theoretical boom extension angle in plane } \\
& \text { parallel to thill. }
\end{aligned}
$$

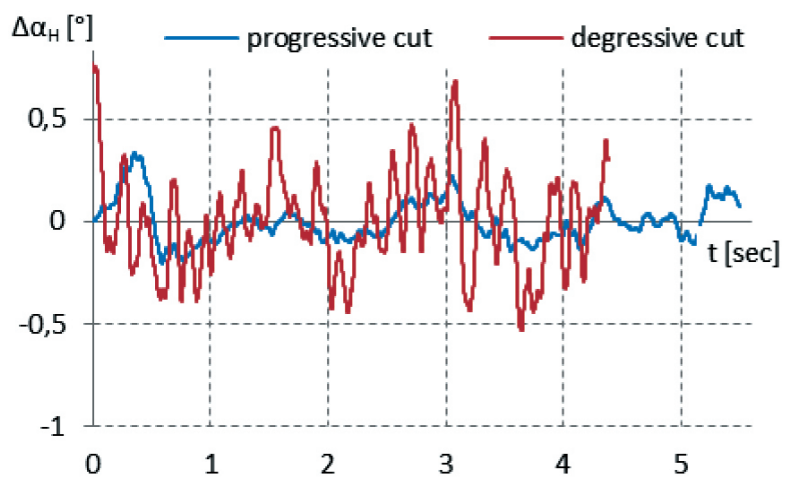

Fig. 11. Course of changes of boom extension angle in plane parallel to thill in relation to theoretical instantaneous position

For the degressive cut, the amplitude of the changes of extension angle $\alpha_{H}$ reached up to $1.2^{\circ}$, and for the progressive cut - up to $0.5^{\circ}$. Similarly, as with the vibrations in the vertical plane and in the case of the vibrations in the horizontal plane, the changes of extension angle $\alpha_{H}$ were much higher while performing the degressive cut than with the progressive cut. The difference was almost 2.5 times higher. From the perspective of guiding the cutterhead, the important fact is that a change of extension angle $\alpha_{H}$ by $1^{\circ}$ in the roadheader used for the study caused the cutterhead to move in the plane parallel to the thill by $56.5-66.8 \mathrm{~mm}$, depending on the assumed value of angle $\alpha_{V}$.

The torsional vibrations of the boom presented in Figures 9 and 11 significantly influenced the actual position of the cutterhead in space in relation to the theoretical position.

The instantaneous resultants of the cutterhead displacements were analyzed separately in relation to each axis of the main Cartesian coordinate system related to the processed concrete block.

$$
\begin{aligned}
& \Delta x=x_{g r}-x_{g t} \\
& \Delta y=y_{g r}-y_{g t} \\
& \Delta z=z_{g r}-z_{g t}
\end{aligned}
$$

where:

$$
\begin{aligned}
x_{g r}, y_{g r}, z_{g r}-\begin{array}{l}
\text { real coordinates of the position of the } \\
\text { cutterhead, }
\end{array} \\
x_{g t}, y_{g t}, z_{g t}-\begin{array}{l}
\text { theoretical coordinates of the position } \\
\text { of the cutterhead resulting from set } \\
\text { parameters and boom movement. }
\end{array}
\end{aligned}
$$

The largest displacements of the cutterhead position were observed for the degressive cut in the vertical direction - " $z$ " axis (Fig. 12). The amplitude of these displacements reached up to $58 \mathrm{~mm}$. For the same direction, the amplitude of the displacements for the progressive cut had a maximum value of $30 \mathrm{~mm}$; however, this was observed only at the beginning of the registered process (at $0.3 \mathrm{~s}$ in the measurement). After that, the amplitude of the displacements remained at a level of $15 \mathrm{~mm}$.

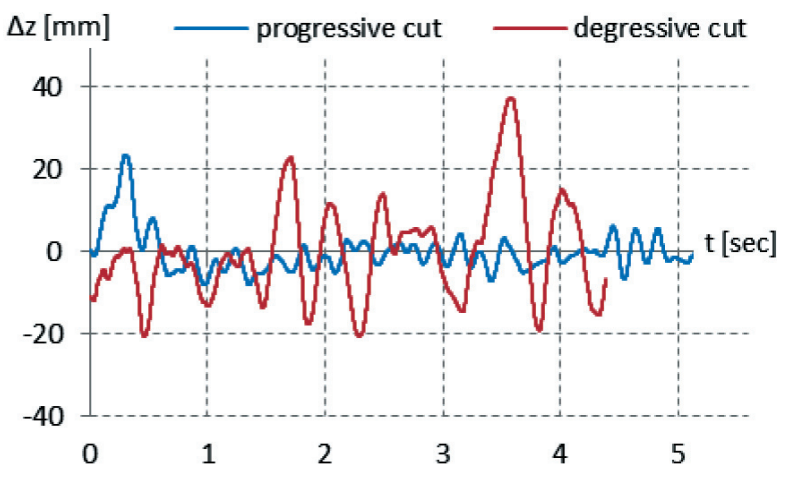

Fig. 12. Course of changes of cutterhead position along " $z$ " axis perpendicular to thill in relation to theoretical instantaneous position 
This was very much different for the change of the cutterhead position along the " $x$ " axis. The deviations of the cutterhead from the theoretical position were significant for both the progressive and degressive cuts (Fig. 13). In the former case, the amplitude of the changes was up to $30 \mathrm{~mm}$, and in the latter - up to $50 \mathrm{~mm}$. In these cases, the period of the main changes of the cutterhead position along the " $x$ " axis was similar or approximately equal to the period of the cutterhead's revolution.

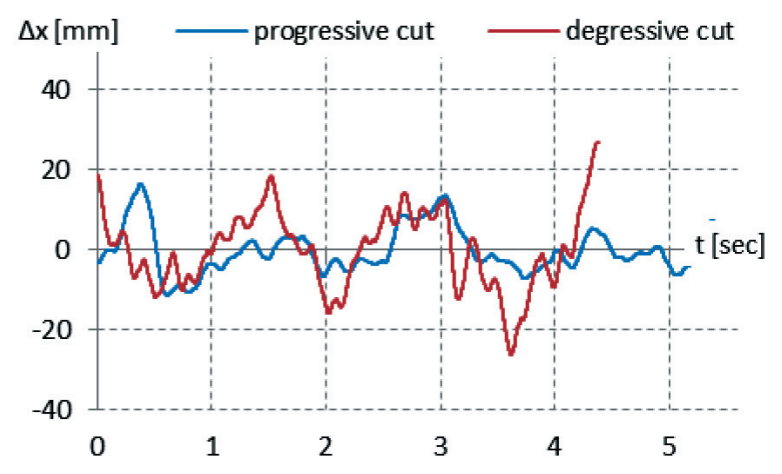

Fig. 13. Course of changes of cutterhead position along " $x$ " axis parallel to thill and perpendicular to roadheader axis in relation to theoretical instantaneous position

The smallest displacement for the progressive and degressive cuts were observed in the direction of the "y" axis, which is the longitudinal axis of the roadheader (Fig. 14).

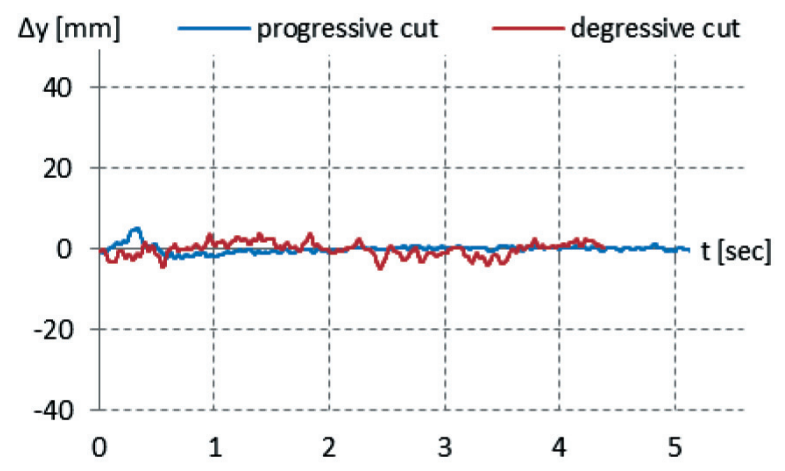

Fig. 14. Course of changes of cutterhead position along " $y$ " axis parallel to thill and roadheader axis in relation to theoretical instantaneous position

The total deviation of the actual position of the cutterhead from the theoretical position derives from the sum of the displacement vectors in relation to a particular axis of the coordinate system.

$$
\Delta R_{x y z}=\sqrt{\Delta x^{2}+\Delta y^{2}+\Delta z^{2}}
$$

Figure 15 shows thetheir comparison for the progressive and degressive cuts.

In the first case, the largest deviation of the cutterhead position from the theoretical position is $27 \mathrm{~mm}$; however, it does not exceed $10 \mathrm{~mm}$ on average. In the second case, the maximum deviation of the cutterhead position was $45 \mathrm{~mm}$ for the degressive cut, with the average deviations remaining at a level of $20 \mathrm{~mm}$.

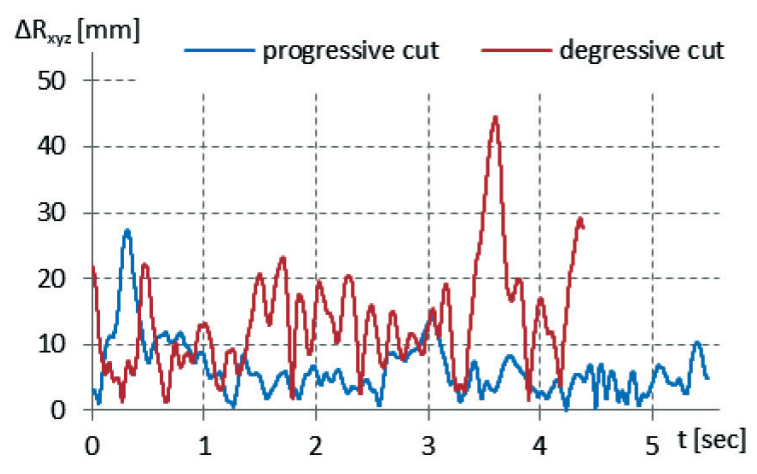

Fig. 15. Course of deviation changes of cutterhead actual position from theoretical position

\section{SUMMARY}

The boom and cutterhead vibrations identified during the course of the study are significant, and they cannot be omitted in the process of modeling the roadheader or when automatically controlling the parameters of the roadheader's excavation system during mining. Furthermore, the registered deviations of the cutterhead position from the set theoretical position are very often higher than the cutting depth of the picks on the cutterhead, which leads to the cutting picks being unable to reach the excavated rock or the cutting depth rising above the theoretical value. Thus, the strong vibrations of the cutterhead cause a significant increase in the work dynamics of the whole roadheader.

Using high-speed cameras for vibration measurements or determining the movement trajectories of objects is quite common in technical industries; however, it is an innovative solution in the mining industry. The main problems when using optical measurement systems are the high dust content, lack of sufficient space around the measured objects, and insufficient lighting. However, under laboratory conditions (such as in the Department of Mining Mechanization and Robotisation of the Silesian University of Technology), these obstacles can be overcome, and 
the optical measurement system with high-speed cameras proved to be a valuable tool in identifying the movements and vibrations of the components of the tested machine.

\section{Acknowledgement}

Work conducted as a part of the project: "Controlling the movement of roadheader cutterheads to decrease energy consumption and dynamic loads" co-financed by National Center of Studies and Research under Applied Research Program (Agreement No. PBS3/B2/15/2015).

\section{References}

[1] Huang H., Lecampion B., Detournay E.: Discrete element modeling of tool-rock interaction I: Rock cutting, "International Journal for Numerical and Analytical Methods in Geomechanics" 2013, 37: 1913-1929.

[2] Cheluszka P., Mann R., Głuszek G.: Determination of the real shape of grooves formed when cutting the rock with conical picks of roadheaders, "Technicka Diagnostika" 2017, 1: 66-74.

[3] Cheluszka P.: Modeling of the geometry of cuts for purpose of the computer simulation of a point-attack picks cutting process, "Technicka Diagnostika" 2015, 1: 66-74.

[4] Dolipski M., Cheluszka P., Sobota P., Bujnowska A.: Кoтputerowe badania wplywu parametrów ruchowych głowic urabiajacych na obciażenie układu urabiania kombajnu chodnikowego, III Międzynarodowy Kongres Górnictwa Rud Miedzi.

[5] Sobota P.: The impact of the roadheader boom settings and pics position on the cutting depth, "Technicka Diagnostika" 2015, 1: 249-257.

[6] Xueyi L., Binbing H., Chaochao L., Shoubo J.: Dynamics Analysis on Roadheader Cutting Head Based on LS-DYNA, "Journal of Convergence Information Technology" 2012, 7: 333-340.

[7] Cheluszka P., Gawlik J.: Computer modelling of roadheader's body vibration generated by the working process, XXVII Symposium "Vibrations in physical systems", Poznań-Będlewo, 9-13.05.2016 r.
[8] Kui-Dong G., Chang-Long D., Song-Yong L.: An empirical mathematic model of drums cutting torque, "Journal of Theoretical and Applied Information Technology" 2012, 46, 2: 785-789.

[9] Tiryaki B., Ayhan M., Hekimoglu O.Z.: A new computer program for cutting head design of roadheaders and drum shearers, 17th International Mining Congress and Exhibition of Turkey - IMCET 2001: 655-662.

[10] Xiang Ping Tang, Duan Yi Wang.: Predication of rock cutting force of conical pick base on RBF Neural Network, "Applied Mechanics and Materials" 2014: 501-504.

[11] Cheluszka P., Remiorz E., Gawlik J.: Simulation investigations of road-header dynamics for automatic control of cutting process, 17th International Multidisciplinary Scientific Geoconference SGEM 2017, 16, 13: 805-815.

[12] Cheluszka P., Mann R., Sobota P., Głuszek G.: The innovative system for measuring the dynamic loads of conical picks on the cutting head of the roadheader, "Technicka Diagnostika" 2016, 1: 53-61.

[13] Cheluszka P., Głuszek G., Giza T., Mann R., Remiorz E., Sobota P.: Charakterystyka uktadu pomiarowego do badań $d y$ namiki kombajnu chodnikowego, Konferencja „Górnictwo Zrównoważonego Rozwoju 2015”, Gliwice 25.11.2015 r.

[14] Cheluszka P.: Identyfikacja geometrii skrawów wykonywanych głowicami poprzecznymi wysiegnikowego kombajnu chodnikowego na podstawie digitalizacji urobionej powierzchni, in: Kotwica K. (red. nauk.), Problemy eksploatacji i zarzadzania w górnictwie, Kraków 2017: 95-105.

RAJMUND MANN, Ph.D., Eng. Faculty of Mining and Geology Silesian University of Technology Akademicka 2a, 44-100 Gliwice, Poland Rajmund.Mann@polsl.pl

KAMIL CZERWINSKI, M.Sc., Eng. KAMIL MATUSIK, M.Sc., Eng. Alstom Konstal S.A.

ul. Metalowców 9, 41-500 Chorzów, Poland \{kamil.czerwinski-ext, kamil.matusik-ext\} @alstomgroup.com 


\title{
Analiza trajektorii ruchu noży i drgań głowicy urabiającej kombajnu chodnikowego z wykorzystaniem kamer szybkich
}

\begin{abstract}
Do identyfikacji ruchu noży w procesie urabiania głowica urabiająca kombajnu chodnikowego wykorzystano zestaw optyczny, którego głównymi elementami były kamery szybkie. W powiazaniu z programem TEMA Motion 3D przeznaczonym do analizy ruchu na podstawie zarejestrowanego obrazu na filmach umożliwiło to szczegółowa analizę torów ruchu wysięgnika, głowic urabiajacych i noży na głowicach $w$ trakcie skrawania. W artykule przedstawiono proces prowadzenia pomiarów oraz wyniki analizy porównawczej drgań wysięgnika i torów ruchu noży na głowicy urabiającej dla wybranych skrawów: progresywnego i degresywnego.
\end{abstract}

Słowa kluczowe: kamera szybka, kombajn chodnikowy, głowica poprzeczna, skraw progresywny, skraw degresywny, drgania

\section{WSTĘP}

W przypadku urabiania głowicą wielonarządową określenie chwilowego położenia noży jest bardzo istotne dla powiązania ich trajektorii z siłami generowanymi podczas urabiania. Zależnie od prędkości obrotowej głowic urabiających i prędkości wychylania wysięgnika kolejne noże, wchodząc w strefę skrawania, mogą wykonywać nowe skrawy lub wpadać $\mathrm{w}$ bruzdy po poprzednich nożach [1], ponadto zmiany tych parametrów wpływają na kształt przekroju poprzecznego skrawów [2-6]. Analiza przebiegu obciążenia noży, potrzebna do weryfikacji modelu numerycznego kombajnu chodnikowego [7-10] oraz automatycznego sterowania parametrami tej maszyny podczas urabiania [11], wymaga identyfikacji rzeczywistych torów ruchu noży, na których mierzone są siły skrawania, docisku i boczna oraz identyfikacji drgań kombajnu chodnikowego, a zwłaszcza jego podzespołów układu urabiania. Wykorzystanie zewnętrznego (niezwiązanego z maszyną) układu optycznego kamer szybkich, za pomocą którego można $\mathrm{z}$ wystarczającą dokładnością określić zmiany położenia głowic urabiających i noży na głowicach, stanowi metodę alternatywną dla pomiaru bezpośredniego [12]. Biorąc pod uwagę złożoną trajektorię ruchu poprzecznej głowicy urabiającej, na której noże w czasie urabiania poruszają się ruchem spiralnym po powierzchni torusa oraz na którą nakładają się drgania wysięgnika i całej maszyny, wykorzystanie optycznego układu pomiarowego do identyfikacji przemieszczeń wybranych punktów na wysięgniku i na głowicy urabiającej kombajnu chodnikowego okazało się dobrym rozwiązaniem.

\section{STANOWISKO BADAWCZE}

Pomiary przeprowadzono na stanowisku badawczym [13] w Katedrze Mechanizacji i Robotyzacji Górnictwa Wydziału Górnictwa i Geologii Politechniki Śląskiej, zbudowanym w ramach projektu naukowo-badawczego „Sterowanie ruchem głowic urabiających kombajnu chodnikowego dla potrzeb obniżenia 
energochłonności urabiania i obciążeń dynamicznych" dofinansowanego ze środków NCBiR.

W celu wykonania pomiarów optycznych określających ruch głowicy urabiającej stanowisko pomiarowe musiało zostać dodatkowo odpowiednio przygotowane (rys. 1). Jednym z podstawowych wymagań analizy obrazu jest sfilmowanie razem z poruszającym się obiektem stałych punktów odniesienia, względem których można zorientować układy współrzędnych w przestrzeni. Zastosowana do pomiarów technika wymagała, żeby punkty odniesienia znajdowały się na jednej płaszczyźnie. W warunkach stanowiska badawczego jedynym spełniającym te wymogi rozwiązaniem było zakotwiczenie do bloku betonowego płyty z odpowiednimi znacznikami - markerami typu quadrant. Płytę tę umieszczono powyżej planowanych do wykonania skrawów.

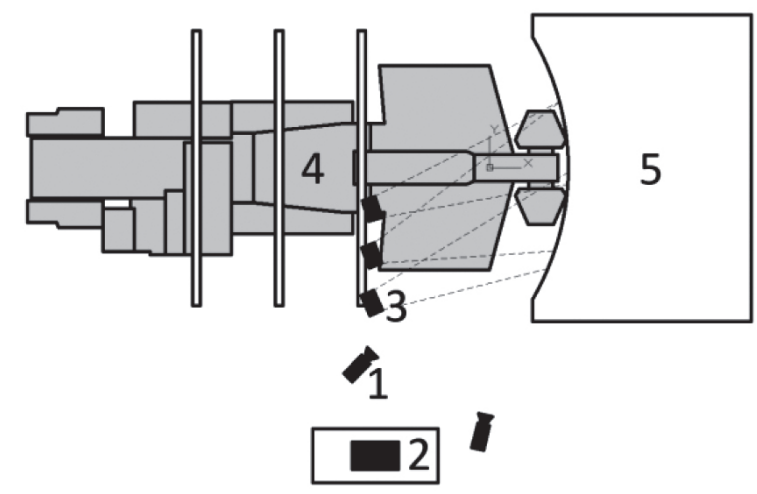

Rys. 1. Schemat rozmieszczenia elementów optycznego układu pomiarowego na stanowisku badawczym: 1 - kamery, 2 - stanowisko sterowania kamerami, 3 - oświetlenie, 4 - kombajn chodnikowy, 5 - blok betonowy

Kolejnym warunkiem koniecznym do przeprowadzenia analizy ruchu obiektów w przestrzeni trójwymiarowej jest ich filmowanie jednocześnie $\mathrm{z}$ dwóch kamer zsynchronizowanych ze sobą czasowo, ustawionych względem filmowanych obiektów tak, żeby kąt pomiędzy osiami optycznymi kamer zawierał się w określonym dla tej techniki pomiarowej przedziale. Kamery zamontowane na statywach rozmieszczono więc możliwie najszerzej $\mathrm{z}$ boku stanowiska badawczego.

Równie istotne, jak rozmieszczenie kamer wokół stanowiska badawczego, było odpowiednie jego oświetlenie. Filmowanie z ultrakrótkimi czasami rejestracji poszczególnych klatek filmu wymaga bardzo silnego stałego (niepulsującego) światła. Do oświetlenia stanowiska wykorzystano specjalne panele oświet- leniowe LED, które umieszczono na łukach obudowy chodnikowej, na stanowisku badawczym, kierując strumień światła z każdego z nich, tak aby koncentrowały się w miejscu wykonywania pomiarów. Zyskana w ten sposób moc świetlna pozwoliła na rejestrację filmów z częstotliwością $1000 \mathrm{~Hz}$, przy czasie ekspozycji pojedynczej klatki filmu wynoszącym $2 \times 10^{-5} \mathrm{~s}$. Tak krótki czas ekspozycji wymagany był w celu uniknięcia smużenia (rozmycia spowodowanego ruchem filmowanych obiektów) na zarejestrowanym filmie.

Rozmieszczenie kamer na stanowisku badawczym i zastosowanie w nich odpowiednich obiektywów pozwoliło na kadrowanie obejmujące ten sam obszar dla obu kamer, w którym zawarte były: końcówka wysięgnika kombajnu, prawa głowica urabiająca, tablica ze znacznikami oraz miejsce urabiania w centralnej części przodka bloku betonowego na szerokości około 1,5 m (rys. 2).

a)

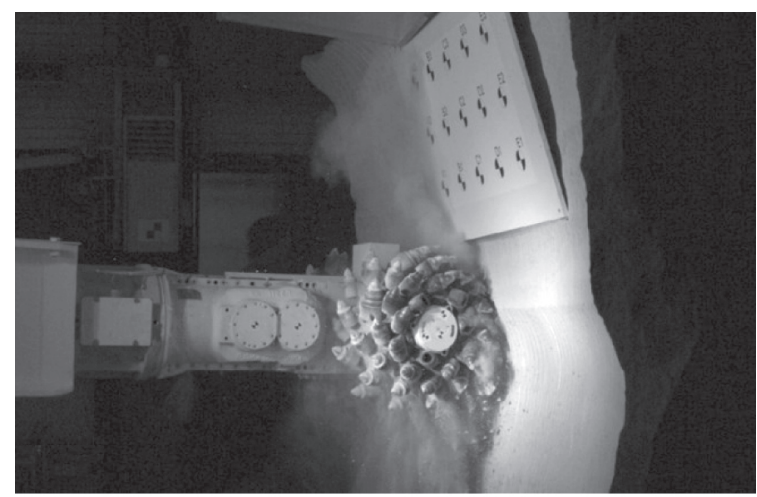

b)

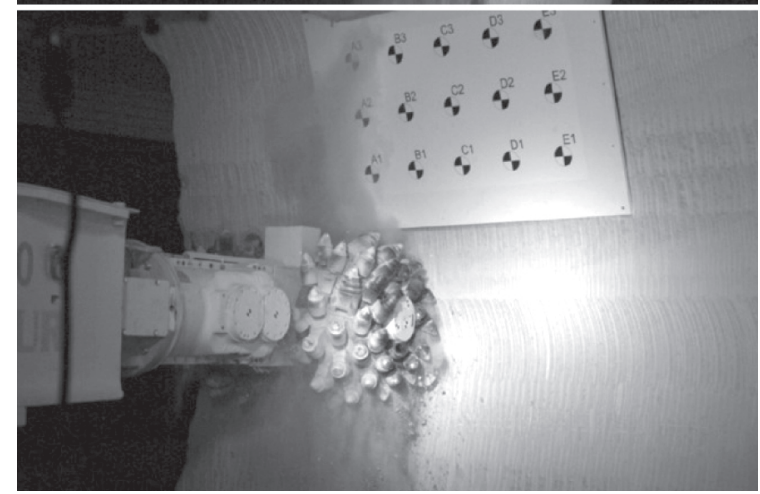

Rys. 2. Widok filmowanego obszaru z kamer prawej (a) i lewej (b) na stanowisku badawczym podczas urabiania

Identyfikacja ruchu głowicy urabiającej i wysięgnika wymagała zastosowania również na tych obiektach znaczników umożliwiających w późniejszej analizie jednoznaczne określanie zmian ich położenia. W celu określenia zmian położenia wysięgnika naklejono na nim dwa znaczniki na pokrywach kół zębatych przekładni redukcyjnej napędu głowic urabiających. Natomiast w celu określenia trajektorii ruchu głowicy 
urabiającej, ze względu na to, że wykonuje ona również ruch obrotowy, naklejono trzy znaczniki na pokrywie bocznej głowicy.

$\mathrm{Na}$ tak przygotowanym stanowisku badawczym filmowano proces urabiania bloku betonowego w pięciosekundowych ujęciach. Był to maksymalny czas, na który pozwalała wbudowana pamięć kamer szybkich. Czas ten w zależności od ustalonej prędkości obrotowej głowic pozwalał na rejestrację od trzech do pięciu pełnych obrotów głowic urabiających.

\section{PRZETWARZANIE DANYCH POMIAROWYCH}

Analizę ruchu przeprowadzono, wykorzystując program TEMA Motion 3D. Polegała ona na określeniu położenia na zarejestrowanych obrazach, znaczników z tablicy kontrolnej, wysięgnika i głowicy urabiającej, wyznaczeniu wspólnego dla obu kamer przestrzennego układu współrzędnych, wyznaczeniu współczynników korekcji dystorsji obiektywów (w celu wyeliminowania krzywizny obrazów) i prześledzeniu zmian położenia znaczników (rys. 3) na kolejnych klatkach zarejestrowanych filmów.

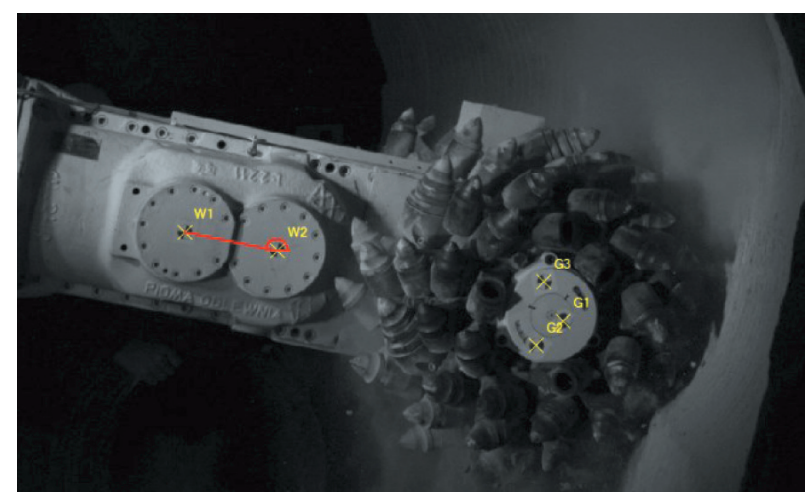

Rys. 3. Kadr z interfejsu programu do analizy obrazu

TEMA Motion 3D - wirtualne punkty śledzenia na wysięgniku i głowicy

W wyniku przeprowadzonych operacji otrzymano współrzędne (x, y, z) znaczników na tablicy kontrolnej oraz na głowicy urabiającej (rys. 4) i wysięgniku, odwzorowujące ich kolejne położenia na torze, po którym się poruszały.

Wyznaczone w programie TEMA Motion 3D współrzędne punktów określające tor ruchu głowicy urabiającej zostały wyeksportowane do arkusza kalkulacyjnego, a następnie dopasowano do nich współrzędne punktów określających rozmieszczenie ostrzy noży na wirtualnym modelu głowicy urabiającej, uzyskanym ze skanera 3D. Wzajemne powiązanie układów współrzędnych modelu głowicy urabiającej i toru ruchu głowicy urabiającej pozwoliło na określenie toru ruchu noży na głowicy urabiającej.

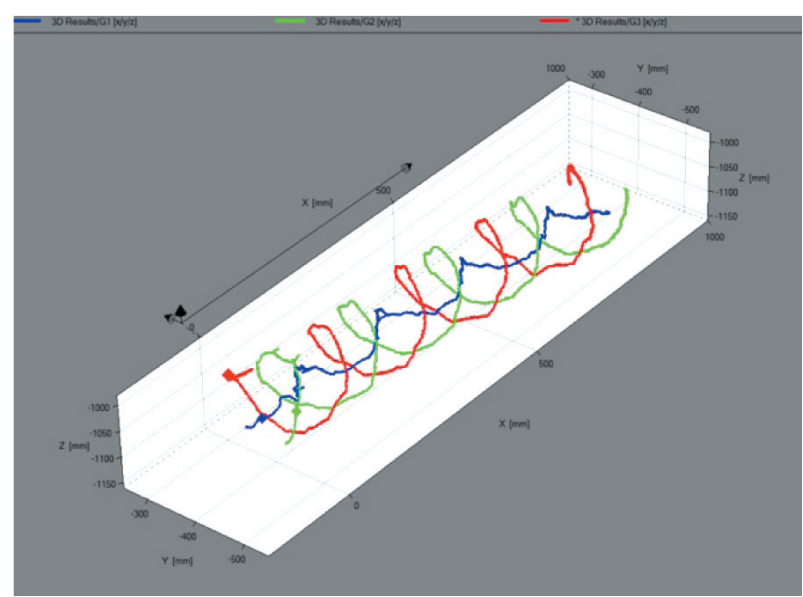

Rys. 4. Tory ruchu znaczników na głowicy urabiającej podczas wykonywania jednego ze skrawów

Ostatecznie wszystkie wyznaczone tory ruchu zorientowano w kartezjańskim układzie współrzędnych związanym z blokiem betonowym. Środek tego układu znajdował się w prawym dolnym rogu bloku. Oś y skierowana była $\mathrm{w}$ głąb bloku betonowego, natomiast płaszczyzna xz pokrywała się z płaszczyzną czoła bloku, w które głowice urabiające kombajnu były zawrębiane, przy czym oś z skierowana była pionowo.

Przykładowe tory ruchu znaczników na wysięgniku kombajnu oraz wyznaczone tory ruchu ostrzy trzech wybranych noży przedstawiono na rysunku 5.

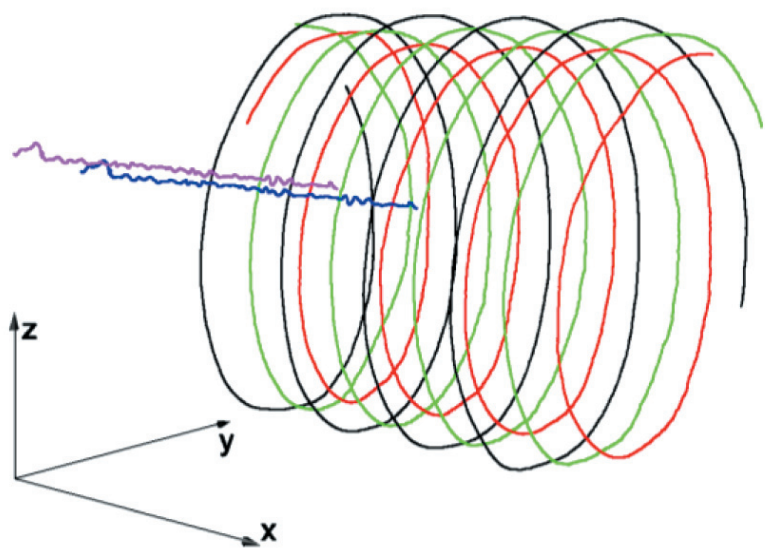

Rys. 5. Tory ruchu znaczników na wysięgniku oraz ostrzy trzech noży na głowicy urabiajacej podczas wykonywania jednego ze skrawów

W trakcie przeprowadzania analizy ruchu wysięgnika wyznaczono wartości błędów pomiarowych na 
podstawie przebiegów czasowych zmierzonych położeń punktów W1 i W2 na wysięgniku oraz wyznaczonej odległości między nimi (rys. 6).

$$
\begin{aligned}
& L_{w 1 w 2}=\sqrt{\left(\Delta x_{w}\right)^{2}+\left(\Delta y_{w}\right)^{2}+\left(\Delta z_{w}\right)^{2}} \\
& \Delta x_{w}=x_{w 2}-x_{w 1} \\
& \Delta y_{w}=y_{w 2}-y_{w 1} \\
& \Delta z_{w}=z_{w 2}-z_{w 1}
\end{aligned}
$$

gdzie $x_{w 1, w 2}, y_{w 1, w 2}, z_{w 1, w 2}-$ zmierzone współrzędne położenia punktów W1 i W2

Odległość między naklejonymi na korpus wysięgnika znacznikami wynosiła $200 \mathrm{~mm}$. Odległość ta mierzona $\mathrm{w}$ trakcie ruchu wysięgnika układem optycznym kamer zmieniała się o $2 \mathrm{~mm}$, co oznacza błąd pomiarowy rzędu $1 \%$. Błędy te były spowodowane głównie zapyleniem, drganiami przenoszącymi się na konstrukcję budynku, w którym prowadzono pomiary, oraz nieprecyzyjnym wyznaczeniem korekty dystorsji obiektywów. $\mathrm{Z}$ uwagi na fakt, że położenie w przestrzeni głowicy urabiającej wyznaczane było analitycznie na podstawie położenia punktów W1 i W2, wyniki przedstawionej w artykule analizy obarczone są podobnym błędem.

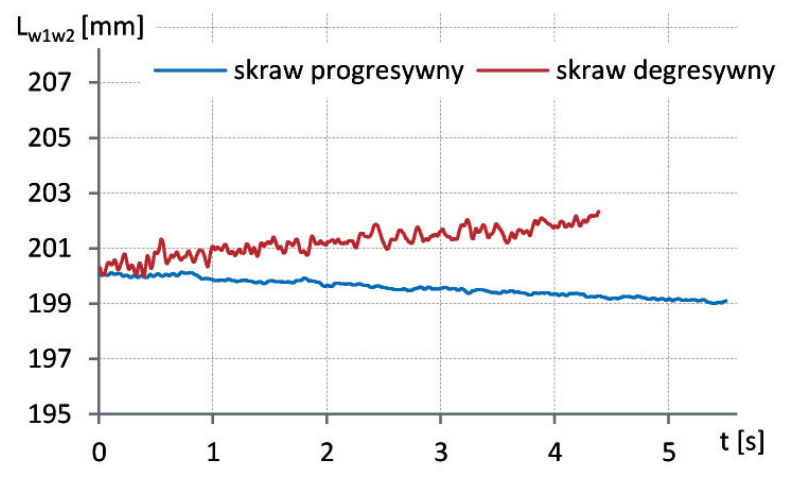

Rys. 6. Określenie wielkości błędu pomiarowego na podstawie odległości punktów W1 i W2

\section{TORY RUCHU NOŻY I DRGANIA WYSIĘGNIKA}

W niniejszym rozdziale przedstawiono wybrane wyniki analizy drgań wysięgnika kombajnu i tory ruchu noży na głowicy urabiającej z dwóch rodzajów skrawów progresywnego i degresywnego, wykonanych przy prędkości obrotowej głowicy urabiającej $44,8 \mathrm{obr} / \mathrm{min}$.
Skrawy progresywne to takie, w których głębokość skrawania stopniowo narasta - najczęściej począwszy od wartości zerowej. W przypadku kombajnu chodnikowego wyposażonego w głowice poprzeczne powstają one w trakcie urabiania czoła przodka poziomymi ruchami wysięgnika, wtedy gdy urabiana jest warstwa skały poniżej istniejącego wcześniej wyłomu (rys. 7). Ze względu na usytuowanie tych skrawów w stosunku do skrawu poprzedniego nazywa się je również skrawami dolnymi.

Z kolei skrawy degresywne to takie, w których nóż rozpoczyna skrawanie z pewną początkową głębokością, która jest najczęściej maksymalną głębokością skrawu, a następnie głębokość skrawu stopniowo maleje (rys. 7). Skrawy te powstają w wyniku podniesienia głowic urabiających i urabiania warstwy skały powyżej istniejącego wyłomu, dlatego są one inaczej nazywane skrawami górnymi.

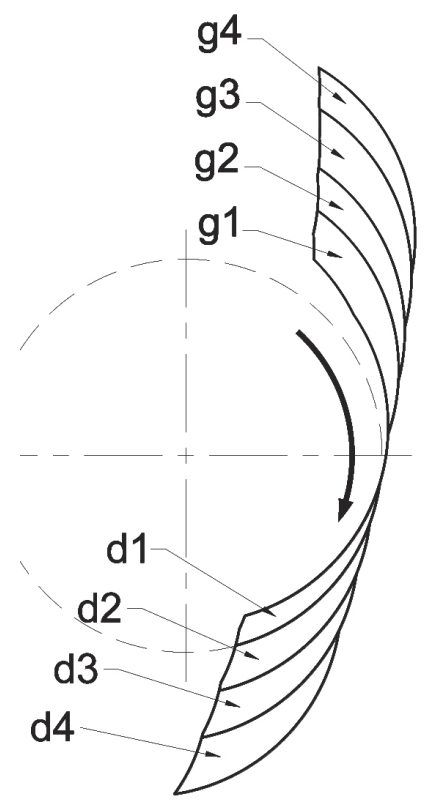

\section{Rys. 7. Kolejno wykonywane skrawy poprzecznymi głowicami kombajnu chodnikowego: \\ $d$-dolne (progresywne), g-górne (degresywne)}

W trakcie wychylania wysięgnika w płaszczyźnie równoległej do spągu noże osadzone na poprzecznej głowicy urabiającej poruszają się teoretycznie ruchem śrubowym po powierzchni torusów. Jednak ze względu na drgania wysięgnika spowodowane procesem urabiania tory te ulegają zaburzeniu, co skutkuje z kolei różnicami pomiędzy rzeczywistym a teoretycznym kształtem skrawów [14]. Na rysunku 8 przedstawiono wyznaczone rzeczywiste tory ruchu trzech noży w układzie współrzędnych związanym z głowicą urabiającą, gdzie oś x' pokrywa się $\mathrm{z}$ teoretyczną osią 
obrotu głowicy. Czarnymi liniami przerywanymi przedstawiono na rysunku okręgi będące odzwierciedleniem teoretycznych torów ruchu wybranych noży. W przypadku przedstawionych torów ruchu noży odchylenia w kierunku osi y' są znacznie mniejsze niż odchylenia w kierunku osi z'.

$$
\begin{aligned}
& z_{i}^{\prime}=z_{i}-z_{g t} \\
& y_{i}^{\prime}=y_{i} \cdot \cos \alpha_{H r}+x_{i} \cdot \sin \alpha_{H r}-y_{g t}
\end{aligned}
$$

gdzie:

$$
\begin{aligned}
x_{i}, y_{i}, z_{i}- & \text { wyznaczone współrzędne ostrza } i \text {-tego } \\
& \text { noża w przyjętym głównym układzie } \\
& \text { współrzędnych, } \\
y_{g t}, z_{g t}- & \text { teoretyczne współrzędne położenia głowi- } \\
& \text { cy urabiającej wynikające z zadanych pa- } \\
& \text { rametrów ustawienia i ruchu wysięgnika, } \\
\alpha_{H r}- & \text { rzeczywisty kąt wychylenia wysięgni- } \\
& \text { ka w płaszczyźnie równoległej do spągu. }
\end{aligned}
$$

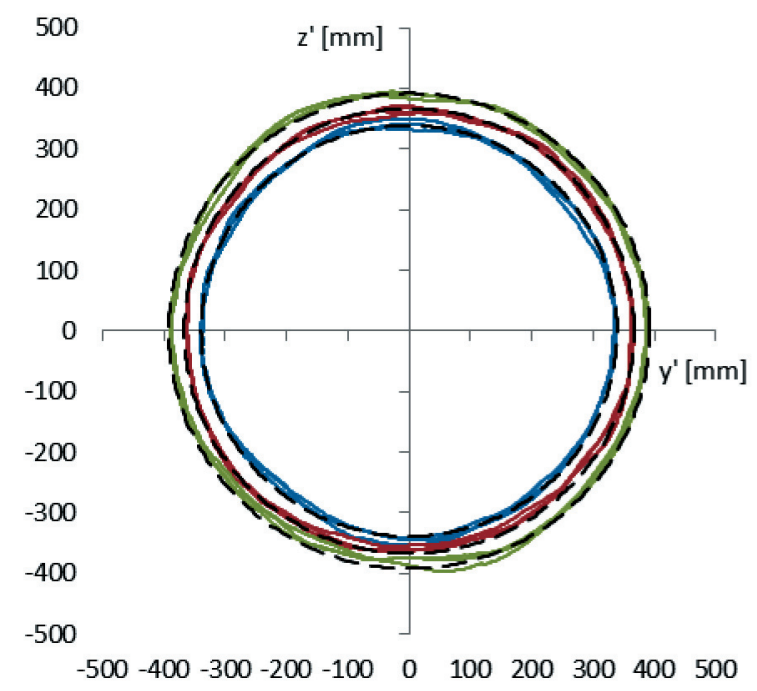

Rys. 8. Odchylenia rzeczywistych torów ruchu noży od torów teoretycznych spowodowane drganiami głowicy, przedstawione w ptaszczyźnie prostopadtej do osi obrotu głowicy

Określenie wielkości drgań wysięgnika i osadzonej na nim głowicy urabiającej na podstawie torów ruchu noży jest utrudnione ze względu na ich ruch obrotowy względem osi obrotu głowicy. Dlatego analizę drgań głowicy przeprowadzono, wykorzystując punkty odniesienia umieszczone na korpusie wysięgnika.

$\mathrm{Na}$ wypadkowe położenie głowicy urabiającej względem jej teoretycznego położenia wpływają drgania całego korpusu maszyny oraz drgania wysięgnika względem korpusu (chwilowe zmiany kąta wychylenia wysięgnika w płaszczyznach prostopadłej i równole- głej do spągu). Wielkość kadru na filmach pozwoliła na określenie zarówno drgań kątowych wysięgnika, jak i wypadkowych drgań głowicy urabiającej podczas procesu urabiania.

Wykonywanie przedstawionego $\mathrm{w}$ artykule skrawu progresywnego odbywało się przy teoretycznie ustalonym kącie wychylenia wysięgnika w płaszczyźnie prostopadłej do spągu $\alpha_{V}=-12,78^{\circ}$, a skrawu degresywnego przy kącie $\alpha_{V}=-2,08^{\circ}$. W celu bezpośredniego porównania intensywności drgań wysięgnika wartości te potraktowano jako punkt odniesienia równy $0^{\circ}$ (rys. 9).

$$
\Delta \alpha_{V}=\alpha_{V r}-\alpha_{V t}
$$

gdzie:

$\alpha_{V r}-$ rzeczywisty kąt wychylenia wysięgnika w płaszczyźnie prostopadłej do spągu,

$\alpha_{V t}$ - teoretyczny (ustalony) kąt wychylenia wysięgnika w płaszczyźnie prostopadłej do spągu.

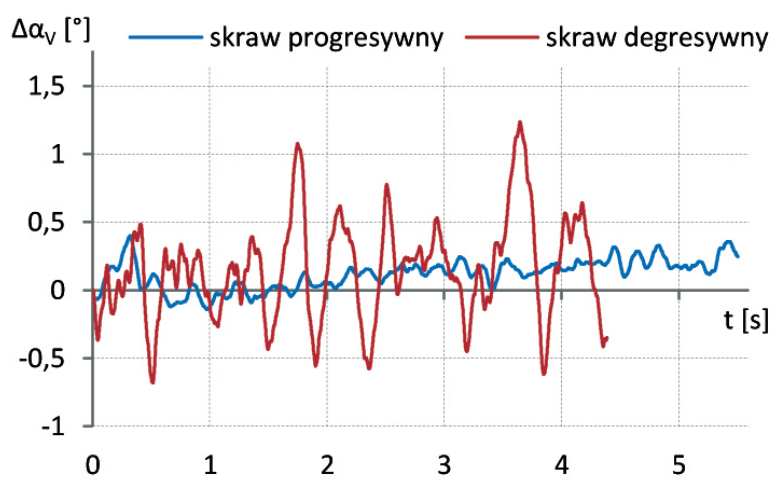

Rys. 9. Przebieg zmian kąta wychylenia wysiegnika w ptaszczyźnie prostopadtej do spagu względem ustawienia teoretycznego

Jak wynika z przedstawionych przebiegów, amplituda przemieszczeń kątowych wysięgnika w płaszczyźnie prostopadłej do spągu podczas wykonywania skrawu degresywnego była nawet 3,5 razy większa niż przy skrawie progresywnym. Dla skrawu degresywnego dochodziła do $1,7^{\circ}$, podczas gdy dla skrawu progresywnego do $0,5^{\circ}$. Przemieszczenia wysięgnika o kąt $\alpha_{V}$ wywołane drganiami znacząco wpływają na rzeczywiste położenie głowicy urabiającej. Zmiana kąta $\alpha_{V}$ o $1^{\circ}$, w analizowanym typie kombajnu chodnikowego, powoduje przemieszczenie głowicy w płaszczyźnie prostopadłej do spągu o $54 \mathrm{~mm}$.

W trakcie urabiania poziomymi warstwami kąt wychylenia wysięgnika w płaszczyźnie prostopadłej do spagu $\alpha_{V}$ pozostaje teoretycznie bez zmian, natomiast kąt wychylenia wysięgnika w płaszczyźnie równoległej 
do spagu $\alpha_{H}$ zmienia się, co jest wynikiem ruchu obrotnicy kombajnu. W przedstawionych przypadkach urabiania wysięgnik był wychylany w płaszczyźnie równoległej do spągu z prędkością kątową wynoszącą średnio dla skrawu degresywnego $\omega_{H}=0,06 \mathrm{rad} / \mathrm{s}$, a dla skrawu progresywnego $\omega_{H}=0,04 \mathrm{rad} / \mathrm{s}$ (rys. 10).

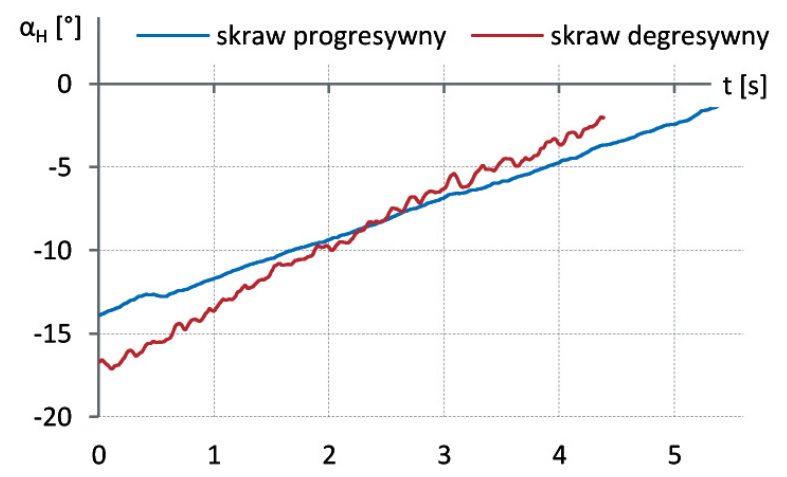

Rys. 10. Przebieg kąa wychylenia wysięgnika w ptaszczyźnie równoległej do spagu

W celu analizy zmian (drgań) kąta wychylenia $\alpha_{H}$ teoretyczne chwilowe wartości tego kąta wynikające z ruchu obrotnicy potraktowano jako punkty odniesienia i przypisano im wartość $0^{\circ}$ (rys. 11).

$$
\Delta \alpha_{H}=\alpha_{H r}-\alpha_{H t}
$$

gdzie:

$$
\begin{aligned}
\alpha_{H r}- & \text { rzeczywisty kąt wychylenia wysięgnika } \\
& \text { w płaszczyźnie równoległej do spągu, } \\
\alpha_{H t}- & \text { teoretyczny kąt wychylenia wysięgnika } \\
& \text { w płaszczyźnie równoległej do spągu. }
\end{aligned}
$$

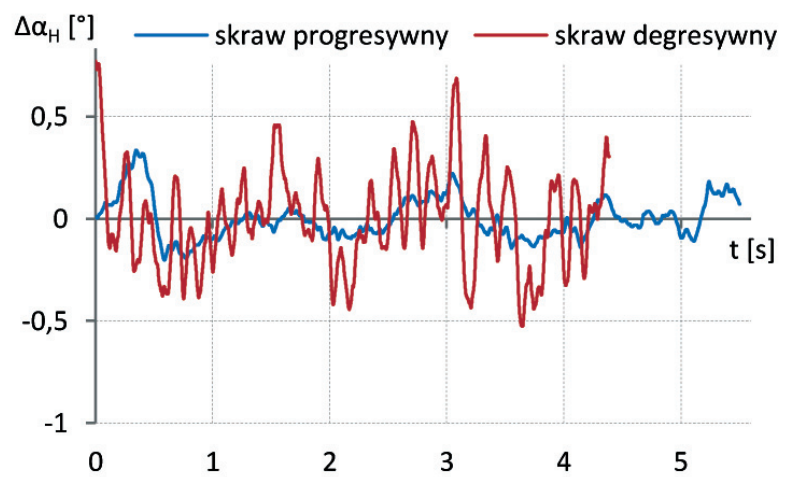

Rys. 11. Przebieg zmian kata wychylenia wysięgnika w ptaszczyźnie równoległej do spagu względem chwilowego potożenia teoretycznego

W przypadku skrawu degresywnego amplituda zmian kąta wychylenia $\alpha_{H}$ dochodziła do $1,2^{\circ}$, a w przypadku skrawu progresywnego do $0,5^{\circ}$. Podobnie jak przy drganiach w płaszczyźnie pionowej również w przypadku drgań w płaszczyźnie poziomej zmiany kąta wychylenia $\alpha_{H}$ w skrawie degresywnym były znacznie większe niż w skrawie progresywnym. Różnica ta była prawie 2,5 -krotna. Istotny z punktu widzenia prowadzenia głowicy jest fakt, że zmiana kąta wychylenia $\alpha_{H}$ o $1^{\circ} \mathrm{w}$ zastosowanym w badaniach kombajnie chodnikowym powoduje przemieszczenie głowicy w płaszczyźnie równoległej do spągu od 56,5 mm do $66,8 \mathrm{~mm}$, w zależności od przyjętej wartości kąta $\alpha_{V}$.

Drgania kątowe wysięgnika przedstawione na rysunkach 9 i 11 wpływaja zasadniczo na rzeczywiste położenie głowicy urabiającej w przestrzeni, w stosunku do położenia teoretycznego.

Wypadkowe, chwilowe przemieszczenia głowicy urabiającej rozpatrzono osobno względem każdej z osi głównego kartezjańskiego układu współrzędnych związanego $\mathrm{z}$ urabianym blokiem betonowym.

$$
\begin{aligned}
& \Delta x=x_{g r}-x_{g t} \\
& \Delta y=y_{g r}-y_{g t} \\
& \Delta z=z_{g r}-z_{g t}
\end{aligned}
$$

gdzie:

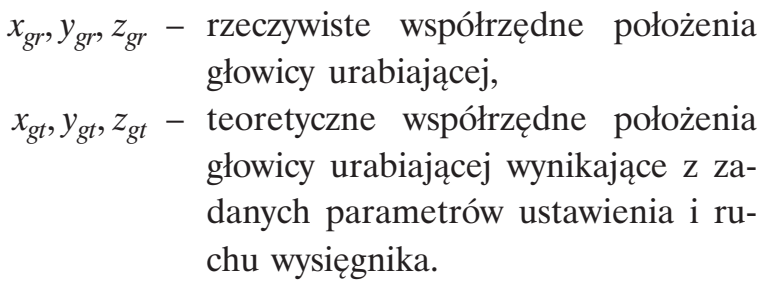

Największe przemieszczenia położenia głowicy urabiającej zaobserwowano dla skrawu degresywnego wzdłuż kierunku pionowego - osi z (rys. 12). Amplituda tych przemieszczeń dochodziła do $58 \mathrm{~mm}$. Dla tego samego kierunku, amplituda przemieszczeń, w przypadku skrawu progresywnego, wynosiła maksymalnie $30 \mathrm{~mm}$, przy czym w zarejestrowanym przebiegu miało to miejsce tylko na jego początku $(0,3 \mathrm{~s}$ pomiaru), a następnie amplituda przemieszczeń utrzymywała się na poziomie $15 \mathrm{~mm}$.

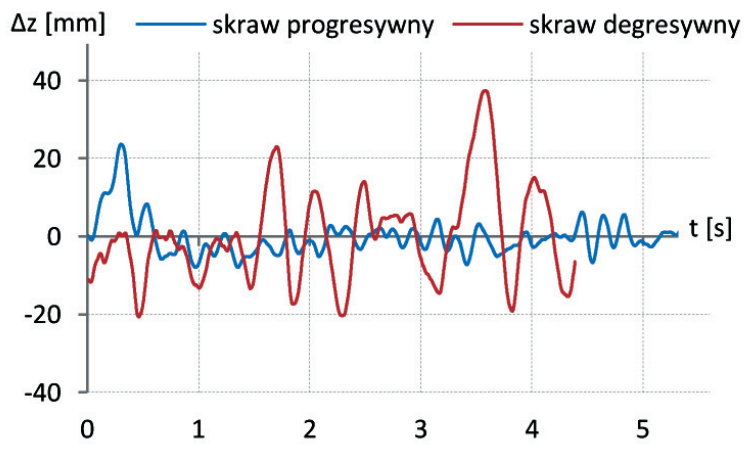

Rys. 12. Przebieg zmian położenia głowicy wzdtuż osi z prostopadtej do spagu względem chwilowego potożenia teoretycznego 
Inaczej przedstawiały się zmiany położenia głowicy wzdłuż osi x. Zarówno w przypadku skrawu progresywnego, jak i degresywnego odchylenia głowicy od położenia teoretycznego były znaczące (rys. 13). W pierwszym przypadku zakres zmian dochodził do $30 \mathrm{~mm}$, w drugim do $50 \mathrm{~mm}$. W przypadkach tych okres głównych zmian położenia głowicy wzdłuż osi x był podobny i równy w przybliżeniu okresowi obrotu głowicy urabiającej.

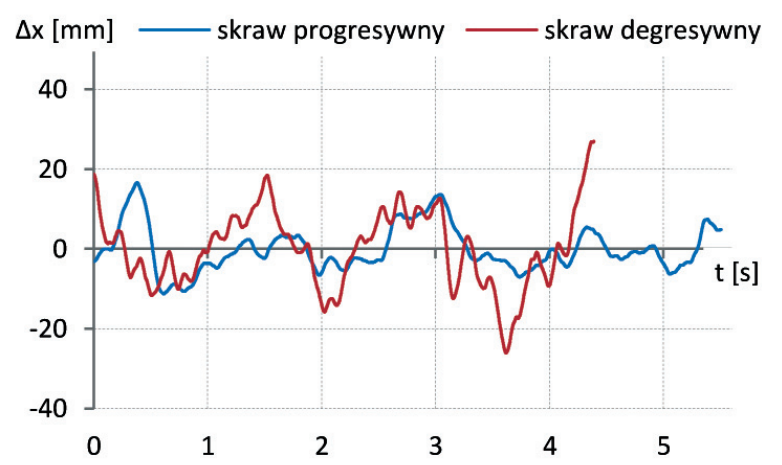

Rys. 13. Przebieg zmian położenia głowicy wzdłuż osi $x$ równoległej do spagu i prostopadłej do osi kombajnu względem chwilowego położenia teoretycznego

Najmniejsze przemieszczenia zarówno w przypadku skrawu progresywnego, jak i degresywnego odnotowano w kierunku osi y, czyli wzdłuż osi podłużnej kombajnu (rys. 14).

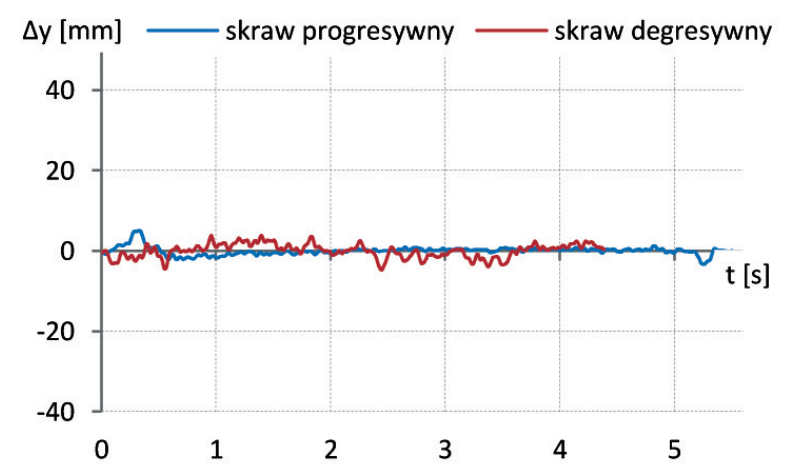

Rys. 14. Przebieg zmian położenia głowicy wzdtuż osi y równoległej do spagu oraz do osi kombajnu względem chwilowego położenia teoretycznego

Całkowite odchylenie położenia rzeczywistego głowicy urabiającej od położenia teoretycznego wynika z sumy wektorów przemieszczeń względem poszczególnych osi układu współrzędnych.

$$
\Delta R_{x y z}=\sqrt{\Delta x^{2}+\Delta y^{2}+\Delta z^{2}}
$$

Na rysunku 15 porównano je dla skrawu progresywnego i degresywnego.

W pierwszym przypadku największe odchylenie położenia głowicy od położenia teoretycznego wynosiło $27 \mathrm{~mm}$, ale przeciętnie nie przekraczało $10 \mathrm{~mm}$. W drugim przypadku, dla skrawu degresywnego, maksymalne odchylenie położenia głowicy wynosiło $45 \mathrm{~mm}$ przy przeciętnych odchyleniach utrzymujących się na poziomie $20 \mathrm{~mm}$.

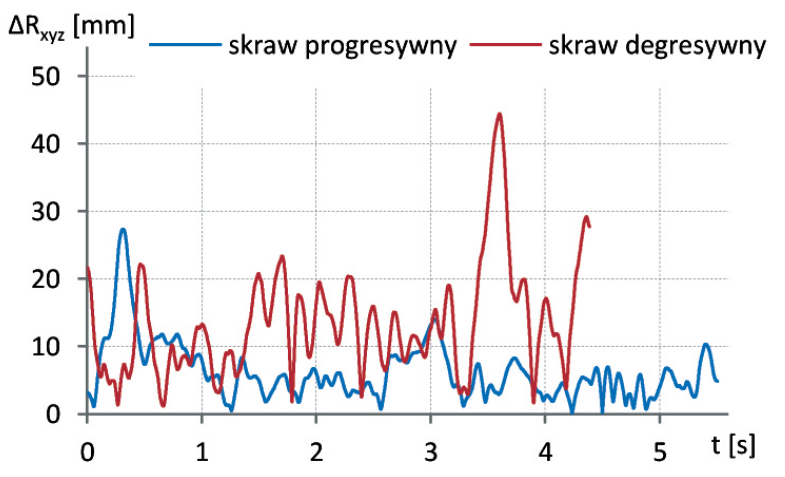

Rys. 15. Przebieg zmian odchylenia położenia rzeczywistego gtowicy od położenia teoretycznego

\section{PODSUMOWANIE}

Zidentyfikowane w trakcie badań drgania wysięgnika i głowicy urabiającej są znaczace i nie można ich pominąć w procesie modelowania kombajnu chodnikowego lub automatycznego sterowania parametrami układu urabiania kombajnu w trakcie urabiania. Tym bardziej, że zarejestrowane odchylenia położenia głowicy urabiającej od zadanego położenia teoretycznego są często większe niż głębokość skrawania noży na głowicy, przez co noże urabiające tracą kontakt z urabianą skałą lub głębokość skrawania wzrasta ponad wartość teoretyczną. Silne drgania głowicy urabiającej powodują zatem istotny wzrost dynamiki pracy całego kombajnu chodnikowego.

Zastosowanie kamer szybkich do pomiaru drgań lub określenia torów ruchu obiektów jest dość powszechne w technice, lecz w branży górniczej stanowi nowatorskie rozwiązanie. Głównymi przeszkodami do stosowania optycznych układów pomiarowych są: duże zapylenie, brak wystarczającej przestrzeni wokół badanych obiektów i niewystarczające natężenie światła. Jednak w warunkach laboratoryjnych, jakimi dysponuje Katedra Mechanizacji i Robotyzacji Górnictwa Politechniki Śląskiej, udało się pokonać te przeszkody, a optyczny układ pomiarowy z kamerami 
szybkimi okazał się cennym narzędziem służącym do identyfikacji ruchu i drgań podzespołów badanej maszyny.

\section{Podziękowania}

Praca zrealizowana w ramach projektu pt. „Sterowanie ruchem głowic urabiających kombajnu chodnikowego dla potrzeb obniżenia energochłonności urabiania i obciążeń dynamicznych" dofinansowanego ze środków Narodowego Centrum Badań i Rozwoju w ramach Programu Badań Stosowanych (umowa nr PBS3/B2/15/2015).

\section{Literatura}

[1] Huang H., Lecampion B., Detournay E.: Discrete element modeling of tool-rock interaction I: Rock cutting, „International Journal for Numerical and Analytical Methods in Geomechanics" 2013, 37: 1913-1929.

[2] Cheluszka P., Mann R., Głuszek G.: Determination of the real shape of grooves formed when cutting the rock with conical picks of roadheaders, „Technicka Diagnostika” 2017, 1: 66-74.

[3] Cheluszka P.: Modelling of the geometry of cuts for purpose of the computer simulation of a point-attack picks cutting process, „Technicka Diagnostika” 2015, 1: 66-74.

[4] Dolipski M., Cheluszka P., Sobota P., Bujnowska A.: Komputerowe badania wplywu parametrów ruchowych głowic urabiajacych na obciażenie układu urabiania kombajnu chodnikowego, III Międzynarodowy Kongres Górnictwa Rud Miedzi.

[5] Sobota P.: The impact of the roadheader boom settings and pics position on the cutting depth, „Technicka Diagnostika” 2015, 1: 249-257.

[6] Xueyi L., Binbing H., Chaochao L., Shoubo J.: Dynamics Analysis on Roadheader Cutting Head Based on LS-DYNA, „Journal of Convergence Information Technology” 2012, 7: 333-340.

[7] Cheluszka P., Gawlik J.: Computer modelling of roadheader's body vibration generated by the working process, XXVII Symposium „Vibrations in physical systems”, Poznań - Będlewo, 9-13.05.2016.
[8] Kui-Dong G., Chang-Long D., Song-Yong L.: An empirical mathematic model of drums cutting torque, ,Journal of Theoretical and Applied Information Technology" 2012, 46, 2: 785-789.

[9] Tiryaki B., Ayhan M., Hekimoglu O.Z.: A new computer program for cutting head design of roadheaders and drum shearers, 17th International Mining Congress and Exhibition of Turkey - IMCET 2001: 655-662.

[10] Xiang Ping Tang, Duan Yi Wang.: Predication of rock cutting force of conical pick base on RBF Neural Network, „Applied Mechanics and Materials" 2014: 501-504.

[11] Cheluszka P., Remiorz E., Gawlik J.: Simulation investigations of road-header dynamics for automatic control of cutting process, 17th International Multidisciplinary Scientific Geoconference SGEM 2017, 16, 13: 805-815.

[12] Cheluszka P., Mann R., Sobota P., Głuszek G.: The innovative system for measuring the dynamic loads of conical picks on the cutting head of the roadheader, „Technicka Diagnostika” 2016, 1: 53-61.

[13] Cheluszka P., Głuszek G., Giza T., Mann R., Remiorz E., Sobota P.: Charakterystyka uktadu pomiarowego do badań dynamiki kombajnu chodnikowego, Konferencja „Górnictwo Zrównoważonego Rozwoju 2015”, Gliwice 25.11.2015.

[14] Cheluszka P.: Identyfikacja geometrii skrawów wykonywanych głowicami poprzecznymi wysiegnikowego kombajnu chodnikowego na podstawie digitalizacji urobionej powierzchni, w: Kotwica K. (red. nauk.), Problemy eksploatacji i zarzadzania w górnictwie, Kraków 2017: 95-105.

dr inż. RAJMUND MANN

Wydziat Górnictwa i Geologii Politechnika Śląska

ul. B. Krzywoustego 2, 44-100 Gliwice Rajmund.Mann@polsl.pl

mgr inż. KAMIL CZERWINSKI

mgr inz. KAMIL MATUSIK Alstom Konstal S.A. ul. Metalowców 9, 41-500 Chorzów \{kamil.czerwinski-ext, kamil.matusik-ext\} @alstomgroup.com 